\title{
PENGARUH KUALITAS PELAYANAN KERETA COMMUTER INDONESIA TERHADAP KEPUASAN WISATAWAN DOMESTIK PADA ERA KENORMALAN BARU
}

\author{
Nosita Elika $^{1}$, I Made Sendra ${ }^{2}$, Ni Putu Eka Mahadewi ${ }^{3}$ \\ Email: nositaelikasentosa@gmail.com¹, sendramade65@gmail.com², eka.mahadewi23@gmail.com³ \\ 1,2,3Program Studi Industri Perjalanan Wisata, Fakultas Pariwisata, Universitas Udayana
}

\begin{abstract}
The Indonesian Commuter Train is a favorite mass transportation for traveling in greater Jakarta because of its affordable price, proximity of the station to tourist destinations, and the services provided. In fact, the management has prepared special Passenger Service officers. There was a decline in passengers in 2019 due to passenger dissatisfaction with the services provided, even the ratio of the number of passenger complaints in 2019-2020 was still the same. In fact, as a commitment to the continued operation during the pandemic, the management launched a special Passenger Service officer named C-Ranger to disseminate health protocols during the new normal. This study uses mixed methods data analysis techniques including qualitative and quantitative descriptive analysis. The research sample determination technique uses purposive sampling with a sample size of 100 respondents. The results of the study show services provided by Passenger Service are ticketing, information service, complaint handling, CCTV access information, priority passenger, pregnant wowen, Lost and Found, and CRanger. Based on the $\mathrm{t}$ test showed that partially, the variables with tangible, assurance, and reliability variables had a significant influence on the satisfaction of domestic tourists. While the variables of empathy and responsiveness do not have a significant effect on the satisfaction of domestic tourists. simultaneously the quality of Passenger Service has a significant and positive influence on the satisfaction of domestic tourists with a coefficient of determination of $50.7 \%$.
\end{abstract}

\begin{abstract}
Abstrak: Kereta Commuter Indonesia adalah transportasi massal favorit untuk berwisata di Jabodetabek karena harganya yang terjangkau, kedekatan stasiun dengan destinasi wisata, dan pelayanan yang diberikan. Bahkan, Manajemen meyiapkan petugas khusus pelayanan penumpang bernama Passenger Service. Terjadi penurunan penumpang pada tahun 2019 akibat ketidakpuasan penumpang terhadap pelayanan yang diberikan, bahkan rasio jumlah keluhan penumpang tahun 20192020 masih sama. Padahal, sebagai komitmen atas tetap beroperasi di masa pandemi, manajemen meluncurkan petugas Passenger Service khusus bernama C-Ranger untuk mesosialisasikan mengenai protokol kesehatan di masa kenormalan baru. Penelitian ini menggunakan teknik analisis data mixed methods meliputi analisis deskriptif kualitatif dan kuantitatif. Teknik penentuan sampel penelitian menggunakan purposive sampling dengan jumlah sampel sebesar 100 orang responden. Hasil penelitian menunjukan bentuk-bentuk pelayanan yang diberikan adalah ticketing, pelayanan informasi, penanganan keluhan, pelayanan informasi CCTV, Penumpang prioritas, ibu hamil, Lost and Found, dan C-Ranger. Berdasarkan uji t menunjukkan bahwa secara parsial, variabel yang bukti fisik, variabel jaminan, dan variabel kehandalan memiliki pengaruh signifikan terhadap kepuasan wisatawan. Sedangkan pada variabel empati dan daya tanggap tidak memiliki pengaruh signifikan terhadap kepuasan wisatawan. secara simultan kualitas pelayanan Passenger Service memiliki pengaruh signifikan dan positif terhadap kepuasan wisatawan domestik dengan nilai koefisien determinasi sebesar $50.7 \%$.
\end{abstract}

Keywords: quality service, satisfaction, domestic tourist, commuter, new normal, passenger service. 


\section{PENDAHULUAN}

Sektor pariwisata yang sedang lesu akibat terdampak pandemi virus corona sejak akhir tahun 2019 dan masuk ke Indonesia sejak Bulan Maret 2020, berdampak pada penurunan wisatawan mancanegara seiring dengan pengurangan penerbangan internasional begitupun dan wisatawan domestik yang sangat berpengaruh terhadap keberlangsungan pariwisata di Indonesia. Namun, sejak kenormalan baru dalam rangka memulihkan ekonomi negara dan adanya vaksinasi membuat perlahan pariwisata pulih kembali. Selain, vaksinasi upaya lain untuk memulihkan pariwisata agar menjadi lebih baik ialah dengan memperhatikan esensi dari pariwisata itu sendiri yakni, kualitas pelayanan yang diberikan, harus memiliki ketepatan waktu, akurasi pelayanan, kesopanan dan keramahan, kemudahan mendapatkan pelayanan, kenyamanan dalam memperoleh pelayanan, dan atribut pendukung pelayanan (Tjiptono 1995, 25). Selain kualitas pelayanan, Pariwisata memiliki 4 komponen pokok, yaitu komponen 4A Attraction (atraksi), Amenity (Fasilitas), Ancilliary (Pelayanan Tambahan), dan Accessibility (Aksesibilitas) (Cooper, dkk 1995, 81).

Aksesibilitas mencakup sarana dan infrastruktur yang memberikan kemudahan kepada wisatawan untuk bergerak dari satu daerah ke daerah lain. Ada cukup banyak jenis transportasi massal darat yang tersedia di Jabodetabek, namun transportasi massal yang memiliki jalur sendiri seperti TransJakarta, Kereta Commuter Indonesia, and Moda Raya Terpadu (MRT) cukup diminati sebagai transportasi wisata karena dinilai lebih efektif dan efisien dari segi waktu dan biaya.

Jumlah pengguna transportasi massal tertinggi dipegang oleh Kereta Commuter Indonesia dengan rata-rata pengguna 269 juta per tahun, Kereta Commuter Indonesia yang menjadi the best choice for urban transport. Kereta Commuter Indonesia dinilai sangat efektif dan efisien untuk mendukung mobilitas masyarakat dalam beraktifitas. Harga tiket yang sangat murah, yakni mulai dari Rp. 3000,- dan keamanan yang cukup terjamin karena memiliki perlintasan sendiri, sehingga cukup menekan angka kecelakaan dibandingkan transportasi umum lainnya. Selain itu, disediakannya pelayanan bagi para penumpang mulai dari stasiun kedatangan hingga stasiun tujuan juga turut membuat penumpang merasa aman dan nyaman. kini banyak masyarakat yang memanfaatkan kehadiran Kereta Commuter Indonesia untuk berkunjung ke berbagai tempat wisata. Terbukti dari anjuran Dinas Pariwisata DKI Jakarta kepada wisatawan untuk menggunakan salah satu transportasi andalan, Kereta Commuter Indonesia untuk beriwisata di Jakarta dan sekitarnya (Dinas Pariwisata Provinsi DKI Jakarta, 2021) dalam program \#VisitJakarta atau \#JalanJalankeJakarta.

Kereta Commuter Indonesia menjadi pilihan moda transportasi bagi wisatawan domestik selain karena Kereta Commuter Indonesia sudah menghubungkan seluruh Kota di Jabodetabek, juga dapat digunakan untuk mengakses berbagai destinasi wisata di DKI Jakarta dan sekitarnya. Penumpang Kereta Commuter Indonesia di Jabodetabek cenderung fluktuatif. Pertumbuhan penumpang 2015-2018 terus mengalami peningkatan, namun mulai mengalami penurunan sedikit di tahun 2019 akibat dari adanya ketidakpuasan penumpang terhadap pelayanan yang diberikan dan turun tajam di tahun 2020 terjadi karena akibat dari pandemi virus corona yang melanda dunia dan mulai masuk ke Indonesia dengan konfirmasi kasus pertama pada 2 maret 2020 lalu.

Berdasarkan data, terdapat 13.604 total keluhan di sepanjang tahun 2019 dan 3.103 ribu keluhan di sepanjang tahun 2020 diseluruh stasiun yang tersebar di Jabodetabek. Sebagai bukti ketidakpuasan penumpang terhadap pelayanan yang diberikan. Memang terlihat penurunan yang cukup signifikan dari tahun sebelumnya. Tetapi, perlu diingat bahwa jumlah penurunan keluhan penumpang seimbang dengan turunnya jumlah penumpang, yakni sebesar $77 \%$ dari tahun 2019 ke tahun 2020 atau dengan kata lain, jumlah keluhan penumpang di tahun 2019 ke tahun 2020 masih sama. Padahal, visi misi Kereta Commuter Indonesia adalah memberikan pelayanan terbaik. Sementara, penurunan jumlah penumpang Kereta Commuter Indonesia karena imbas dari pandemi virus corona dan pertimbangan protokol kesehatan yang diterapkan seperti, pembatasan dan pelarangan penumpang, juga pengurangan jadwal keberangkatan.

Salah satu pihak yang berperan penting dalam garda terdepan untuk memberikan 
pelayanan kepada penumpang Kereta Commuter Indonesia adalah Passenger Service. Passenger Service merupakan representatif manajemen PT. Kereta Commuter Indonesia di stasiun, sebagai petugas pelayanan penumpang. Dengan dipertahankannya pengoperasian Kereta Commuter Indonesia oleh pemerintah DKI Jakarta di tengah pandemi pada masa kenormalan baru ini membuat pihak manajemen Kereta Commuter Indonesia berupaya untuk terus meningkatkan kualitas pelayanan dengan diadakannya petugas CRanger yang merupakan Passenger Service milenial berpakaian merah-putih yang tugasnya berfokus pada sosialisasi 3M (Memakai Masker, Mencuci Tangan, dan Menjaga Jarak), ditambah aspek Cleanliness (Kebersihan), Health (Kesehatan), Safety (Keamanan), dan Environment (CHSE) (Ramah lingkungan) di setiap stasiun yang sekarang menjadi prioritas utama di Kereta Commuter Indonesia demi kemanan dan kenyamanan wisatawan.

Berdasarkan hasil observasi pendahuluan, kebanyakan wisatawan domestik memberikan keluhan terhadap pelayanan Passenger Service. Seperti kurang cepatnya pelayanan, kurang banyaknya personil, kurangnya keramahan petugas, kurang perhatian personal terhdap wisatawan, dan penggunaan alat pelindung diri yang belum benar. Kondisi ini secara langsung maupun tidak langsung akan mempengaruhi kepuasan wisatawan domestik, walaupun sebenarnya, inti pelayanan yang diberikan sudah baik. Kegagalan Passenger Service dalam memenuhi harapan wisatawan domestik dapat membuat citra Kereta Commuter Indonesia menjadi buruk. Hal ini terjadi karena adanya perbedaan antara pelayanan yang diharapkan dengan pelayanan yang diterima oleh wisatawan domestik. Maka dari itu, kualitas pelayanan yang diberikan harus sesuai dengan harapan wisatawan domestik hingga dapat menimbulkan sikap positif pada wisatawan domestik, dengan kata lain pelayanan tersebut mampu memberikan kepuasan wisatawan domestik. Berdasarkan uraian di atas maka, penulis tertarik untuk mengangkat judul "Pengaruh Kualitas Pelayanan Passenger Service terhadap Kepuasan wisatawan domestik Kereta Commuter Indonesia Pada Era Kenormalan Baru. Untuk mengetahui apa saja bentuk-bentuk pelayanan yang diberikan oleh Passenger Service kepada wisatawan domestik di Kereta Commuter Indonesia, bagaimana kualitas layanan yang diberikan oleh Passenger Service kepada wisatawan domestik di Kereta Commuter Indonesia dan seberapa besar pengaruhnya terhadap kepuasan wisatawan domestik di Kereta Commuter Indonesia. Dengan demikian, Kereta Commuter Indonesia dapat terus mengoptimalkan pelayanan Passenger Service di seluruh stasiun dan tetap menjadi transportasi pilihan utama wisatawan domestik untuk berwisata terutama di masa pandemi virus corona ini maupun di masa yang akan datang. Maka, berdasarkan uraian latar belakang diatas, didapatkan tujuan penelitian berikut untuk mengetahui bentuk-bentuk pelayanan yang diberikan oleh Passenger Service kepada wisatawan domestik di Kereta Commuter Indonesia Pada Era Kenormalan Baru. Untuk mengetahui pengaruh variable bukti fisik, daya tanggap, jaminan, empati, dan kehandalan secara parsial terhadap kepuasan wisatawan domestik di Kereta Commuter Indonesia Pada Era Kenormalan Baru. Serta untuk mengetahui pengaruh variabel kualitas Pelayanan secara simultan terhadap kepuasan wisatawan domestik di Kereta Commuter Indonesia Pada Era Kenormalan Baru.

\section{METODE}

Penelitian ini berlokasi di beberapa Stasiun Kereta Commuter Indonesia yang berada di wilayah Jabodetabek. Karena keterbatasanwaktu, peneliti hanya mengambil beberapa stasiun yang dianggap cukup mewakili karakteristik penumpang di seluruh stasiun yakni, Stasiun Jakarta Kota, Stasiun Bogor, dan Stasiun Tangerang yang menjadi tujuan wisata disaat akhir pekan atau hari libur. Adapun variabel kualitas pelayanan yang digunakan dalam penelitian ini berdasarkan teori Sunyoto (2012) yakni:

1. Bukti Fisik: Peralatan APD lengkap (Masker, Sarung Tangan, dan Face shield), Kartu Master, dan Petugas mengenakan seragam yang rapi dan bersih

2. Daya Tanggap: Kecepatan merespon penumpang, kemampuan memberikan solusi, dan komunikatif dalam pelayanan

3. Jaminan: Kemampuan petugas dalam menimbulkan rasa percaya diri konsumen, petugas mampu membuat konsumen merasa aman dari tindak kejatahan, petugas mampu membuat konsumen terbebas dari rasa khawatir dari paparan virus Covid-19, 
petugas mampu membuat konsumen merasa nyaman, hasil pelayanan bagus, ketrampilan melayani, dan petugas sopan \& ramah

4. Empati: Petugas mampu berkomunikasi dengan baik kepada konsumen, petugas mengerti keinginan konsumen, memberikan kemudahan kepada konsumen

5. Kehandalan: Memberikan pelayanan yang sesuai dengan masalah yang dihadapi penumpang, ketelitian melayani konsumen, pelayanan tepat waktu, kecepatan dalam bekerja, keseriusan menanggapi konsumen

Sementara variabel kepuasan wisatawan menurut Irawan (2008) memiliki indikator perasaan puas akan pelayanan yang diberikan, selalu menggunakan jasa, merekomendasikan kepada orang lain, dan terpenuhinya harapan penumpang setelah menggunakan jasa.

Pengumpulan data dalam penelitian ini dilakukan dengan observasi, wawancara, kuesioner, studi kepustakaan, dan dokumentasi dengan penentuan sampel menggunakan purposive sampling dengan jumlah 100 orang responden menggunakan rumus lemeshow. Teknik pengambilan sampel dengan accidental sampling. Teknik Penentuan Informan dengan purposive sampling dengan Bapak Adli Hakin Nasution sebagai Manajer External Relation and Coorporate Image Care Kereta Commuter Indonesia dan Bapak Tatis Sutrisna sebagai Asisten Manajer Customer Service Kereta Commuter Indonesia karena mereka berada diposisi manajemen menengah yang bertanggung jawab atas seluruh peleyanggaraan aktivitas pelayanan penumpang di Kereta Commuter

Sedangkan informan kunci dalam penelitian ini adalah Bapak Anggana Rahman sebagai Supervisior Passenger Service dan Announcer, dan Bapak Rachmat Santoso sebagai Pengawas On Station Cleaning. Karena mereka bertugas sebagai pengawas lapangan sekaligus penanggung jawab para petugas Passenger Service dan petugas kebersihan stasiun. Juga Petugas Passenger Serice bernama Agus asal Stasiun Bogor, Melani asal Stasiun Jakarta Kota, dan Samsul asal Stasiun Tangerang. Sehingga, informan dapat memberikan informasi secara umum melalui hasil wawancara mengenai gambaran umum, sejarah, perkembangan, deksripsi pekerjaan Passenger Service, dan penerapan CHSE di stasiun.
Dalam penelitian ini teknik analisis data mixed methods meliputi analisis deskriptif kualitatif dan kuantitatif dipadukan dengan penggunaan skala likert.

\section{HASIL DAN PEMBAHASAN}

Passenger Service merupakan peranan yang sangat penting di Kereta Commuter Indonesia. Karena tugas dan tanggung jawab Passenger Service merupakan tujuan, visi, dan misi dari PT. Kereta Commuter Indonesia sendiri. Yakni, memberikan pelayanan yang terbaik dari awal kedatangan wisatawan domestik hingga tujuannya di Kereta Commuter Indonesia. Seperti membantu saat tap in dan tap out (tempat masuk dan keluarnya wisatawan domestik di stasiun) di gate, pelayanan informasi, mengurus Lost and Found (barang wisatawan domestik yang tertinggal atau ditemukan di Kereta Commuter Indonesia), mengurus penumpang prioritas seperti ibu hamil, lansia, penyandang disabilitas, dan orang tua yang membawa anak agar mendapatkan tempat duduk selama di kereta dan pengawasan khusus di kereta dan stasiun.

Walaupun sedang di masa pandemi virus corona, tidak ada perubahan pendapatan bagi Passenger Service tetap sesuai dengan UMR daerah masing-masing stasiun tempat Passenger Service berdinas, tetap mendapatkan tunjangan BPJS Ketenagakerjaan, dan insentif berupa tunjangan keahlian dan tunjangan kerapihan. Jika Passenger Service Melakukan kesalahan maka sanksi yang akan diterima ialah berupa teguran atau Surat Peringatan, I, II, dan III tergantung pada tingkat kesalahan yang dilakukan.

Waktu kerja bagi Passenger Service ialah delapan jam dalam satu hari. Terdapat enam hari kerja dan satu hari libur disetiap minggunya dan tidak ada perubahan selama pandemi virus corona. Secara struktural, Divisi Passenger Service berada dibawah Direktorat Operasi dan Pemasaran. Divisi Passenger Service dikepalai oleh Vice President Hospitality atau pelayanan.

Divisi Passenger Service mulai didirikan sejak 2014 dengan 19 petugas anggota di Stasiun Bogor, Stasiun Tanah Abang, Stasiun Jakarta Kota dan Stasiun Manggarai yang dilatarbelakangi karena diberlakukannya sistem tiket elektronik atau e-ticketing sejak 1 Juli 2013 dengan sarana gerbang elektronik atau 
electronic gate dan Kartu Harian Berjamin, yang menyebabkan perubahan yang cukup besar pada saat itu. Pada awalnya, tugas utama Petugas Passenger Service adalah membantu penumpang untuk tap in dan tap out di Stasiun agar tidak terjadi antrian panjang jika ada yang penumpang yang kesulitan, masalah pada kartu, atau ketidaktahuan penumpang

Seiring berjalannya waktu, Manajemen Kereta Commuter Indonesia menyadari bahwa masih terdapat banyak masalah lain di bidang pelayanan penumpang yang dirasa cocok menjadi tanggung jawab petugas Passenger Service. Seperti banyaknya barang-barang penumpang yang tertinggal di area stasiun, penumpang prioritas, dan di masa pendemi ini, menjadi C-Ranger menjadi alasan dikembangkannya divisi Passenger Service dari segi kuantitas, pelatihan, serta fasilitas yang ditujukan pada divisi ini.

Diawali dengan 19 petugas di 4 stasiun pada tahun 2014 sekarang terdapat 290 petugas Passenger Service di 80 dengan perbandingan gender 50:50 di seluruh stasiun dan tidak ada pengurangan petugas selama pandemi virus corona. Perekrutan Passenger Service sendiri tidak dilaksanakan oleh Kereta Commuter Indonesia, melainkan oleh Kereta Api Wisata (Anak Perusahaan dari PT. Kereta Api Indonesia yang berfokus pada penyewaan gerbong kereta untuk rombongan wisata). Namun, jumlah pelamar dipastikan bertambah.

Deskripsi pekerjaan yang menjadi tanggung jawab Passenger Service juga mengalami perkembangan dari segi jumlahnya sejak awal bedirinya divisi ini dibandingan dengan sekarang terutama di masa pandemi virus corona. Demi meningkatkan kualitas pelayanan yang diberikan, maka pihak manajemen Kereta Commuter Indonesia juga mengembangkan pelatihan-pelatihan baru bagi petugas Passenger Service, berikut merupakan bukti perkembangan pelatihan yang harus dijalani Passenger Service sejak awal beridirinya divisi ini dibandingan dengan sekarang.

Pada awal dibentuknya Divisi Passenger Service hanya mengenakan rompi merah dengan tulisan "Passenger Service" dibagian belakang. Namun saat ini, Petugas Passenger Service sudah memiliki seragam putih berlis merah pada lengan dan kerah dengan logo perusahaan dan divisi di bagian dada dan lengan, dilengkapin dengan bawahan hitam panjang, ikat pinggang, dan sepatu hitam. Semenjak terjadinya Pandemi Virus corona, seragam Passenger Service mengalami perubahan yang berfokus pada penerapan protokol kesehatan yakni, sarung tangan, masker, pelindung wajah atau face shield dan manset jika seragam berlengan pendek. Tak hanya dari segi jumlah petugas, deskripsi pekerjaan, pelatihan dan seragam, penambahan fasilitas bagi Passenger Service pun turut dilakukan demi menunjang pekerjaanpekerjaan mereka. Seperti Ruangan Passenger Service di stasiun, Perangkat PC All In One, Tablet, Stick Grab, dan Pengeras Suara/Megaphone. Penerapan Protokol CHSE di Lingkungan Kereta Commuter Indonesia.

1. Cleanliness (Kebersihan)

Kereta Commuter Indonesia terus berupaya untuk pencegahan penyebaran virus corona baik di kereta maupun distasiun, maka dari itu, dilakukannya pembersihan kereta maupun area stasiun secara rutin dengan memakai disinfektan, dan disediakannya fasilitas tempat cuci tangan pakai sabun di beberapa titik lokasi stasiun seperti di pintu masuk, area peron, dan pintu keluar. Penyemprotan disinfektan di area stasiun secara keseluruhan dilakukan sebanyak 3 kali sehari, sementara di kereta di lakukan setelah dan sebelum kereta digunakan. Untuk area peron, gate, ruang tunggu, dan seluruh area yang sering dilalui oleh wisatawan domestik selama di stasiun dibersihkan secara berkala setiap pergantian flow penumpang.

2. Healthy (Kesehatan)

Penerapan protokol kesehatan di Kereta Commuter Indonesia berupa pengecekan suhu tubuh melalui thermometer gun oleh Passenger Service atau melalui monitor suhu badan otomatis. Standar suhu yang diperbolehkan bagi para wisatawan domestic dalam menggunakan Kereta Commuter Indonesia adalah dibawah $37,3^{\circ}$ Celcius. Jika ditemukan suhu tubuh diatas $37,3^{\circ}$ Celcius, maka wisatawan domestik tidak akan diperkenankan untuk menggunakan Kereta Commuter Indonesia

3. Safety (Keamanan)

Penerapan protokol keamanan (Safety) yang terdapat di Kereta Commuter Indonesia yaitu berupa tersedianya prosedur penanganan wisatawan domestik berupa prosedur pengaturan jarak antar 
individu di lingkungan stasiun maupun kereta ketika mengantri, berdiri ataupun duduk menggunakan sticker. Selain itu, semua petugas yang bertugas di stasiun maupun kereta mengenakan Alat Pelindung Diri atau APD yang terdiri dari masker, pelindung wajah face shield, sarung tangan, dan pakaian lengan panjang.

4. Environmental Sustainability (Kelestraian Lingkungan)

Kereta Commuter Indonesia, menerapkan program "Stasiun Ramah Lingkungan" yang saat ini terdapat di 8 stasiun. Disahkan oleh Kementerian Lingkungan Hidup dan Kehutanan (KLHK) demi menjaga kelestarian lingkungan berupa 3R (Reduce, Reuse \& Recycle). Vertical Garden, dan Eco Charging.

Berdasarkan hasil penelitian, bentukbentuk pelayanan yang diberikan Passenger Service kepada wisatawan domestik di Kereta Commuter Indonesia adalah pelayanan Eticketing. Jika ada wisatawan domestik yang kesulitan Melakukan tap in karena terdapat masalah pada kartu, Passenger Service harus membantu. Berikut tahapannya:

1. Jika kartu tidak terbaca, petugas segera menghimbau agar wisatawan domestik melakukan pengecekan kartu pada mesin balance reader yang biasanya berada di dekat loket atau gate

2. Jika pada mesin balance reader masih belum terbaca, maka dilakukan pengecekan di Sistem Otomatisasi Ticketing Commuter di ruangan staf atau ruangan Passenger Service, untuk mengetahui relasi perjalanan dan tanggal pembelian serta penggunaan perjalanan.

3. Jika terdapat masalah pada kartu, Petugas menjelaskan kepada wisatawan domestik, jika kartu Tiket Harian Berjamin sudah lebih 7 (tujuh) hari dari waktu pembelian terakhir maka kartu Tiket Harian Berjamin sudah tidak dapat lagi digunakan untuk perjalanan menggunakan Kereta Commuter Indonesia.

4. Jika relasi Tiket Harian Berjamin/Kartu MultiTrip kurang bayar atau perjalanan kadaluwarsa karena tidak menyelesaikan perjelananya sebelumnya (tidak melakukan tap out) maka Passenger Service mengarahkan penumpang untuk melakukan transaksi pada mesin penyelaras tarif atau melakukan transaksi di loket penyelaras tarif.

5. Jika ada kartu yang rusak dan tidak dapat digunakan untuk perjalanan, Passenger Service mengarahkan wisatawan domestik melakukan penggantian kartu ke loket atau bank sesuai dengan jenis kartu yang dimiliki.

Jika ada wisatawan domestik yang kesulitan Melakukan tap out karena terdapat masalah pada kartu, Passenger Service harus membantu. Berikut tahapannya:

1. Passenger Service mengarahkan wisatawan domestik untuk mencari tiket yang di gunakan saat tap in saat awal pemberangkatan.

2. Jika wisatawan domestik tidak dapat menunjukan tiket perjalanan saat akan tap out / keluar stasiun, maka dikenakan denda suplisi sebesar Rp 50.000 (lima puluh ribu rupiah) sesuai dengan ketentuan perusahaan.

Passenger Service dituntut agar mengetahui seluruh informasi mengenai:

1. Jadwal berangkat dan tiba kereta.

2. Peta rute kereta.

3. Tarif perjalanan.

4. Barang bawaan atau bagasi.

5. Wilayah dalam stasiun (seperti toilet, mushola, tempat parkir, charging point, kios atau gerai, ATM, ruang menyusui, jalur evakuasi, pos kesehatan, dan peron).

6. Wilayah luar sekitar stasiun (rumah sakit, kantor polisi, pemadam kebakaran, dan tentunya destinasi wisata).

7. Transportasi lanjutan di sekitar stasiun seperti bus, ojek, dll.

Dalam dunia pelayanan, tak terlepas dari keluhan atau komplain. Tugas Passenger Service salah satunya menangani wisatawan domestik dalam penyampaian keluhan dengan cara mendengarkan keluhan lalu mengarahkan penumpang untuk mengisi form keluhan pelanggan, lalu, petugas Passenger Service menindaklanjuti keluhan dengan menyampaikan Form Keluhan Pelanggan kepada Help Desk Commuter Control Room Kereta Commuter Indonesia selanjutnya diberikan nomor tiket sebagai bentuk dokumentasi.

Adapun kelengkapan dokumen yang harus dilengkapi oleh penumpang dalam hal memerlukan untuk melihat rekaman CCTV adalah: 
1. Surat Keterangan Kehilangan dari Kepolisian (Dokumen asli).

2. Surat keterangan kehilangan yang dikeluarkan oleh Stasiun (Dokumen asli).

3. Menandatangani surat penyataan diatas materai (Template surat sudah tersedia di unit pelayanan pada Kantor PT. Kereta Commuter Indonsia di Stasiun Juanda).

Penumpang prioritas dilayani oleh petugas Passenger Service mulai dari penjemputan di luar stasiun, membeli tiket, tap in, kebutuhan pribadi seperti shalat atau ke toilet, menunggu kereta, masuk ke kereta, tiba distasiun tujuan, tap out, lalu diantarkan ke transportasi lanjutan. Pin Ibu hamil juga menjadi tanggung jawab pekerjaan Passenger Service. Cara mendapatkan Pin Khusus Ibu Hamil Ini. dengan 3 cara, yaitu:

1. Daftar Online di https://bit.ly/30DZ20k.

2. Stasiun: Bekasi, Bogor, Juanda, Duri, Sudirman, dan Tanah Abang.

3. Komunitas: Jalur Bekasi, Jalur Depok Bogor, Jalur Nambo, Jalur Serpong, Jalur Duri - Tangerang.

Pin Ibu Hamil bisa diambil di komunitas atau stasiun yang telah disepakati pada saat verifikasi di ruangan Passenger Service di Stasiun untuk dilayani. Pin Khusus Ibu Hamil ini diharapkan dapat membantu mengidentifikasi seluruh ibu hamil, terutama untuk usia kehamilan pada trimester pertama, dimana secara fisik belum terlihat tanda-tanda kehamilan, sehingga ibu hamil tetap bisa mendapatkan kursi di dalam kereta saat melakukan perjalanan dengan Kereta Commuter Indonesia.

Demi meningkatkan kenyamanan dan kepuasan penumpang, dalam menggunakan jasa angkutan Kereta Commuter Indonesia, dihadirkanlah Sistem Lost and Found merupakan suatu bentuk program yang ditujukan untuk memaksimalkan penanganan barang tertinggal. Standar pelayanan Lost and Found ini dikoordinir oleh petugas Passenger Service, yang mencakup penanganan pelaporan barang tertinggal oleh petugas, penanganan pelaporan barang hilang atau tertinggal distasiun dan kereta oleh wisatawan domestik, penanganan penyimpanan penemuan barang, dan proses pengambilan barang.

Kereta Commuter Indonesia menugaskan para pemuda-pemudi divisi Passenger Service berpakaian merah putih untuk ikut serta memberikan edukasi dan sosialisasi kepada wisatawan domestik yang menggunakan Kereta Commuter Indonesia untuk selalu patuh protokol kesehatan 3M (Memakai masker, Mencuci tangan, dan Menjaga jarak) selama berada di lingkungan Kereta Commuter Indonesia baik di kereta maupun di stasiun. Selain itu, juga patuh pada aturan-aturan kenormalan baru seperti tidak berbicara secara langsung maupun melalui sambungan telepon di dalam kereta untuk menghindari penyebaran virus melalui droplet yang bisa keluar melalui mulut dan hidung ketika bersin, bantuk, maupun berbicara. Memakai masker kain atau masker 3 lapis, dilarang memakai masker scuba atau buff karena tidak sesuai standar. Serta dihimbau agar wisatawan yang menggunakan Kereta Commuter Indonesia menggunakan faceshield dan berpakian lengan panjang.

\section{Analisis Pengaruh Kualitas Pelayanan Passenger Service Terhadap Kepuasan Wisatawan Domestik di Kereta Commuter Indonesia}

Berdasarkan hasil analisis dapat diketahui bahwa semua instrumen yang terdiri dari 25 indikator pernyataan yang telah diuji adalah valid, karena melebihi standar minimal dari koefisien korelasi yaitu sebesar 0,361. Menurut Ghozali (2005), instrumen yang mengalami uji reliabilitas dinyatakan reliabel apabila memiliki nilai alpha lebih besar dari 0.6. Berdasarkan Tabel 6 dapat dilihat bahwa dari hasil uji reliabilitas terhadap 25 indikator didapatkan nilai Cronbach's Alpha sebesar 0,912 . Hasil dari uji reliabilitas menyatakan bahwa seluruh instrumen yang digunakan dalam penelitian ini dinyatakan reliabel, karena nilai Cronbach's Alpha yaitu 0,912 lebih besar dari alpha-tabel yaitu 0,600.

Berdasarkan hasil pengolahan data untuk menganalisis regresi linear berganda Kualitas Pelayanan Passenger Service Terhadap Kepuasan Wisatawan Domestik Di Kereta Commuter Indonesia maka dapat diperoleh persamaan regresi berganda berdasarkan hasil penelitian, yaitu $\mathrm{Y}=(1.599)+0.281 \mathrm{X} 1+$ $0.057 \mathrm{X} 2+0.148 \mathrm{X} 3-0.009 \mathrm{X} 4-0.318 \mathrm{X} 5+$ e. Hasil uji t menunjukkan bahwa nilai sig untuk pengaruh $\mathrm{X} 1, \mathrm{X} 3$ dan $\mathrm{X} 5$ terhadap $\mathrm{Y}$ kurang dari 0.05 dan nilai $t$ hitung lebih dari $\mathrm{t}$ tabel maka H1a, H3a, dan H5a diterima dan H1o, H3o, dan H5o ditolak yang berarti terdapat pengaruh X1 (Bukti Fisik), X3 
(Jaminan), dan X5 (Kehandalan) terhadap Y (Kepuasan Wisatawan Domestik). Sementara, hasil uji t menunjukkan bahwa nilai sig untuk pengaruh X2 dan X4 terhadap Y lebih dari 0.05 dan nilai $t$ hitung kurang dari $t$ tabel maka $\mathrm{H} 2 \mathrm{a}$ dan $\mathrm{H} 4 \mathrm{a}$ ditolak dan $\mathrm{H} 2 \mathrm{o}$ dan $\mathrm{H} 4 \mathrm{o}$ diterima, yang berarti tidak terdapat pengaruh X2 (Daya Tanggap), dan X4 (Empati) terhadap Y (Kepuasan Wisatawan Domestik). Dapat disimpulkan bahwa, secara simultan, kualitas pelayanan Passenger Service berpengaruh terhadap kepuasan wisatawan domestik di Kereta Commuter Indonesia karena $\mathrm{F}$ hitung $21.208>\mathrm{F}$ tabel 2.31. Berdasarkan hasil analisis menunjukkan bahwa nilai korelasi dari Kualitas Pelayanan Passenger Service Terhadap Kepuasan Wisatawan Domestik Di Commuter Line adalah $\mathrm{R}=50.7 \%$. Melalui hasil analisis tersebut dapat diartikan bahwa sebesar 50.7\% Kepuasan Wisatawan Domestik di Kereta Commuter Indonesia pengaruhi oleh Kualitas Pelayanan Passenger Service, sementara sisanya dipengaruhi oleh variabel lain seperti tarif, jadwal, dan ketepatan waktu.

Berdasarkan hasil penelitian yang dilakukan melalui wawancara pada pihak Kereta Commuter Indonesia, bentuk-bentuk pelayanan yang dilaksanakan oleh Passenger Service kepada wisatawan domestik di Stasiun adalah pelayanan e-ticketing, pelayanan informasi (mengenai jadwal, rute, stasiun, tarif, dan wilayah sekitar luar stasiun), pelayanan penanganan keluhan, informasi akses CCTV, pelayanan penumpang prioritas (disabilitas dan ibu hamil), Lost and Found, dan C-Ranger (Pelayanan yang dilakukan oleh Passenger Service yang berfokus pada protokol kesehatan selama pandemi virus corona)

Berdasarkan hasil penelitian yang dilakukan pada wisatawan domestik yang melakukan perjalanan di Kereta Commuter Indonesia, pengujian hipotesis (korelasi X1 terhadap Y), Bukti Fisik berpengaruh terhadap kepuasan wisatawan domestik di Kereta Commuter Indonesia. Adapun nilai uji signifikan (uji t) dari variabel bukti fisik (X1) terhadap kepuasan wisatawan domestik di di Kereta Commuter Indonesia (Y), hasil analisis menunjukan bahwa nilai signifikansi sebesar $0.020<0.05$ dengan nilai thitung thitung 2.358 $>\mathrm{t}$ tabel 1.98552. Sehingga Bukti Fisik berpengaruh positif terhadap kepuasan wisatawan domestik di Kereta Commuter Indonesia. Maka, dapat dikatakan bahwa semakin tinggi pengaruh bukti fisik mengenai Kualitas Pelayanan Passenger Service yang terdiri dari kelengkapan APD, kelengkapan kartu master, dan kebersihan \& kerapihan Passenger Service, maka semakin tinggi kepuasan wisatawan domestik terhadap Kereta Commuter Indonesia. Sebaliknya, semakin rendah pengaruh bukti fisik kualitas pelayanan maka semakin rendah pula kepuasan wisatawan domestik di Kereta Commuter Indonesia. Oleh karena itu, Passanger Service harus memerhatikan penampilan dan kelengkapan peralatan pelayanan. Hasil ini sesuai dengan penyampaian tanggapan wisatwan domestik terhadap Passenger Service melalui kuesioner: "Penggunaan Alat Pelindung diri (APD) oleh Passenger Service, sudah lengkap dan benar" (Han, Jabodetabek, Hasil Tanggapan Mengenai Passenger Service, 2021)

Berdasarkan hasil penelitian yang dilakukan pada wisatawan domestik yang melakukan perjalanan di Commuter Line, pengujian hipotesis (korelasi X2 terhadap Y), Daya Tanggap tidak berpengaruh terhadap kepuasan wisatawan domestik di Kereta Commuter Indonesia. Adapun nilai uji signifikan (uji t) dari variabel Daya Tanggap (X2) terhadap kepuasan wisatawan domestik di Kereta Commuter Indonesia (Y), hasil analisis menunjukan bahwa nilai signifikansi $0.733>$ 0.05 dengan $t$ hitung $0.342<\mathrm{t}$ tabel 1.98552 . Sehingga Daya berpengaruh negatif terhadap kepuasan wisatawan domestik di Kereta Commuter Indonesia. Indikator yang digunakan pada variabel Daya Tanggap adalah kecepatan dalam pelayanan, kemampuan memberikan solusi, dan kekomunikatifan petugas. Hasil ini sesuai dengan penyampaian beberapa tanggapan wisatawan domestik terhadap Passenger Service melalui kuesioner:

"Passenger Service kurang cepat dalam menangani masalah yang dihadapi oleh wisatawan domestik" (Ryan, Bandung, Hasil Tanggapan Mengenai Passenger Service, 2021).

"Passenger Service kurang tanggap atau kurang cepat aja dalam melayani, dan kadang ada yang sekali service habis itu ditinggal" (Rafiella Tharob, Tangerang, Hasil Tanggapan Mengenai Passenger Service, 2021). 
Berdasarkan hasil penelitian yang dilakukan pada wisatawan domestik yang melakukan perjalanan di Kereta Commuter Indonesia, pengujian hipotesis (korelasi X3 terhadap Y), Jaminan berpengaruh terhadap kepuasan wisatawan domestik di Kereta Commuter Indonesia. Adapun nilai uji signifikan (uji t) dari variabel Jaminan (X3) terhadap kepuasan wisatawan domestik di Kereta Commuter Indonesia (Y), hasil analisis menunjukan bahwa nilai signifikansi $0.024<$ 0.05 dengan nilai $\mathrm{t}$ hitung $2.295>\mathrm{t}$ tabel 1.98552. Sehingga Jaminan berpengaruh positif terhadap kepuasan wisatawan domestik di Kereta Commuter Indonesia. Maka, dapat dikatakan bahwa semakin tinggi pengaruh jaminan mengenai Kualitas Pelayanan Passenger Service yang terdiri dari kemampuan menimbulkan rasa percaya diri wisatawan domestik dalam mengunakan Kereta Commuter Indonesia di masa pandemi, kemampuan Passenger Service dalam membuat wisatawan domestik merasa aman dari tindak kejahatan, kemampuan Passenger Service dalam membuat wisatawan domestik terbebas dari rasa khawatir terpapar Virus corona melalui kluster transportasi massal, kemampuan Passenger Service dalam membuat wisatawan domestik merasa nyaman dalam menggunakan Kereta Commuter Indonesia di masa pandemi hasil pelayanan yang bagus, keterampilan Passenger Service dalam melayani, dan kesopanan dan keramahan Passenger Service dalam memberikan pelayanan, maka semakin tinggi kepuasan wisatawan domestik terhadap Kereta Commuter Indonesia. Sebaliknya, semakin rendah pengaruh jaminan kualitas pelayanan maka semakin rendah pula kepuasan wisatawan domestik di Kereta Commuter Indonesia. Oleh karena itu, Passanger Service harus berdedikasih dalam melayani wisatawan. Hasil ini sesuai dengan penyampaian beberapa tanggapan wisatawan domestik terhadap Passenger Service melalui kuesioner:

"Pelayanan yang diberikan oleh Passenger Service sudah bagus" (Sarah Wenni, Bogor, Hasil Tanggapan Mengenai Passenger Service, 2021).

"Passenger Service sudah memberikan pelayanan bagus" (Erika, Tangerang, Hasil Tanggapan Mengenai Passenger Service, 2021).
"Pelayanan yang diberikan kepada wisatawan sudah bagus" (Wawan Hermawan, Yogyakarta, Hasil Tanggapan Mengenai Passenger Service, 2021)

Berdasarkan hasil penelitian yang dilakukan pada wisatawan domestik yang melakukan perjalanan di Kereta Commuter Indonesia, pengujian hipotesis (korelasi X4 terhadap Y), Empati tidak berpengaruh terhadap kepuasan wisatawan domestik di Kereta Commuter Indonesia. Adapun nilai uji signifikan (uji t) dari variabel Empati (X4) terhadap kepuasan wisatawan domestik di Kereta Commuter Indonesia (Y), hasil analisis menunjukan bahwa nilai signifikansi $0.961>$ 0.05 dengan t hitung $-0.049<\mathrm{t}$ tabel 1.98552 . Sehingga empati berpengaruh negatif terhadap kepuasan wisatawan domestik di Kereta Commuter Indonesia. Indikator yang digunakan pada variabel empati adalah kemampuan berkomunikasi yang baik, mengerti keinginan wisatawan, dan kemampuan memberikan kemudahan. Hasil ini sesuai dengan penyampaian beberapa tanggapan wisatawan domestik terhadap Passenger Service melalui kuesioner:

"Terkadang masih ada Passenger Service yang kurang ramah dalam menanggapi para wisatawan jadi harapannya kedepannya agar para petugas yang bekerja dalam lingkup perkerjaan tersebut lebih ramah lagi" (Yefiena Liestiyani, Kalimantan, Hasil Tanggapan Mengenai Passenger Service, 2021).

"Terkadang, Passenger Service masih kurang ramah" (Nining Susanti, Banyumas, Hasil Tanggapan Mengenai Passenger Service, 2021).

"Dear Passenger Service, lebih ditingkatkan lagi keramahan dan kepeduliannya ketika ada penumpang yang hendak bertanya ya. Jangan sampai penumpang (1 orang/sendiri) merasa minder dan takut bertanya. (Laurence, Manado, Hasil Tanggapan Mengenai Passenger Service, 2021).

Berdasarkan hasil penelitian yang dilakukan pada wisatawan domestik yang melakukan perjalanan di Kereta Commuter Indonesia, pengujian hipotesis (korelasi X5 terhadap Y), kehandalan berpengaruh terhadap 
kepuasan wisatawan domestik di Kereta Commuter Indonesia. Adapun nilai uji signifikan (uji t) dari variabel kehandalan (X5) terhadap kepuasan wisatawan domestik di Kereta Commuter Indonesia (Y), hasil analisis menunjukan bahwa nilai signifikansi $0.003<$ 0.05 dengan t hitung $3.069>\mathrm{t}$ tabel 1.98552 . Sehingga Kehandalan berpengaruh positif terhadap kepuasan wisatawan domestik di Kereta Commuter Indonesia. Maka, dapat dikatakan bahwa semakin tinggi pengaruh kehandalan mengenai Kualitas Pelayanan Passenger Service yang terdiri dari kemampuan Passenger Service dalam memberikan pelayanan yang sesuai dengan masalah yang dihadapi wisatawan domestik di Kereta Commuter Indonesia, ketelitian petugas dalam melayani wisatawan domestik, ketepatan waktu Passenger Service dalam memberikan pelayanan kepada wisatawan domestik, kecepatan petugas dalam melayani wisatawan domestik, dan keseriusan Passenger Service dalam memberikan pelayanan, maka semakin tinggi kepuasan wisatawan domestik terhadap Kereta Commuter Indonesia. Sebaliknya, semakin rendah pengaruh kehandalan kualitas pelayanan maka semakin rendah pula kepuasan wisatawan domestik di Kereta Commuter Indonesia. Oleh karena itu, Passenger Service harus teliti, tepat waktu, dan serius dalam melayani wisatawan. Hasil ini sesuai dengan penyampaian beberapa tanggapan wisatawan domestik terhadap Passenger Service melalui kuesioner:

"Passenger Service dapat diandalkan dalam memberikan solusi" (Britanny, Bekasi, Hasil Tanggapan Mengenai Passenger Service, 2021 "Passenger Service serius dalam menanggapi wisatawan" (Ungi, Jakarta, Hasil Tanggapan Mengenai Passenger Service, 2021).

Secara keseluruhan atau simultan, Variabel Kualitas Pelayanan berpengaruh terhadap kepuasan wisatawan domestik di Kereta Commuter Indonesia. Berdasarkan hasil uji t, dapat diketahui bahwa daya tanggap, empati, dan kehandalan tidak berpengaruh terhadap kepuasan wisatawan domestik. Secara simultan, kualitas pelayanan berpengaruh terhadap kepuasan wisatawan domestik di Kereta Commuter Indonesia Hasil penelitian ini sesuai dengan penelitian yang dilakukan oleh Oktaviasari, dkk (2019) dengan judul
"Pengaruh Kualitas Pelayanan, Tarif dan Ketepatan Waktu Terhadap Kepuasan Pelanggan" mengatakan bahwa secara parsial kualitas pelayanan berpengaruh positif dan signifikan terhadap kepuasan pelanggan. Hal ini dapat disimpulkan bahwa kualitas pelayanan memegang peranan yang cukup penting dalam mempengaruhi tingkat kepuasan konsumen.

Selain itu, hasil penelitian ini juga sesuai dengan penelitian yang dilakukan oleh Ningsih, dkk (2018) dengan judul "Pengaruh Kualitas Pelayanan Terhadap Kepuasan Konsumen Pada PT. Kereta Api Indonesia (Persero) Divisi Regional II Sumatra Barat Padang Pariaman" yang menyatakan bahwa kualitas pelayanan dari lima (tangible, reliability, responsivennes, assurance, emphaty) secara bersama-sama menunjukan hasil yang signifikan terhadap kepuasan konsumen. Hal ini dapat disimpulkan bahwa dimensi kualitas pelayanan memberikan pengaruh yang cukup nyata terhadap kepuasan konsumen. Hasil penelitian ini juga mendukung pendapat dari Lewis \& Booms dalam Tjiptono \& Chandra (2011 : 180), bahwa kualitas layanan sebagai ukuran seberapa bagus tingkat layanan yang diberikan mampu terwujud sesuai harapan pelanggan yang berakhir dengan kepuasan. Dengan analisis determinasi atau besarnya nilai pengaruh yang diberikan oleh Kualitas Pelayanan Terhadap Kepuasan Wisatawan Domestik di Kereta Commuter Indonesia sebesar $50.7 \%$.

\section{SIMPULAN DAN SARAN Simpulan}

Bentuk-bentuk pelayanan yang diberikan oleh Passenger Service kepada wisatawan domestik di Kereta Commuter Indonesia ialah pelayanan e-ticketing, pelayanan informasi (mengenai jadwal, rute, wilayah stasiun, barang bawaan/bagasi, detinasi wisata, dan tarif) pelayanan penanganan keluhan wisatwan domestik, informasi akses CCTV, pelayanan penumpang prioritas (disabilitas dan ibu hamil), Lost and Found, dan C-Ranger (Pelayanan yang dilakukan oleh Passenger Service yang berfokus pada protokol kesehatan selama pandemi virus corona.

Secara parsial, Variabel Bukti Fisik (X1) berpengaruh terhadap kepuasan wisatawan domestik di Kereta Commuter Indonesia karena nilai signifikansi sebesar $0.020<0.05$ dengan nilai $\mathrm{t}$ hitung $\mathrm{t}$ hitung $2.358>\mathrm{t}$ tabel 1.98552 , Variabel Daya Tanggap (X2) tidak berpengaruh 
terhadap kepuasan wisatawan domestik di Kereta Commuter Indonesia karena nilai signifikansi $0.733>0.05$ dengan $\mathrm{t}$ hitung 0.342 $<\mathrm{t}$ tabel 1.98552, ), Variabel Jaminan (X3) berpengaruh terhadap kepuasan wisatawan domestik di Kereta Commuter Indonesia karena nilai signifikansi $0.024<0.05$ dengan nilai $\mathrm{t}$ hitung $2.295>$ t tabel 1.98552, Variabel Empati (X4) tidak berpengaruh terhadap kepuasan wisatawan domestik di Kereta Commuter Indonesia karena nilai signifikansi $0.961>0.05$ dengan $t$ hitung $-0.049<\mathrm{t}$ tabel 1.98552 , dan Variabel Kehandalan (X5) berpengaruh terhadap kepuasan wisatawan domestik di Kereta Commuter Indonesia karena nilai signifikansi $0.003<0.05$ dengan $t$ hitung 3.069 $>\mathrm{t}$ tabel 1.98552 .

Secara simultan, Variabel Kualitas Pelayanan yang terdiri dari Variable Bukti Fisik, Daya Tanggap, Jaminan, Empati, dan Kehandalan berpengaruh terhadap kepuasan wisatawan domestik di Kereta Commuter Indonesia. besarnya nilai pengaruh yang diberikan oleh Kualitas Pelayanan Terhadap Kepuasan Wisatawan Domestik di Kereta Commuter Indonesia sebesar 50.7\%.

\section{Saran}

Terkait saran akademis bagi penelitian selanjutnya, agar penelitian ini dapat dijadikan acuan maupun referensi untuk penelitian selanjutnya dan perlu dilakukan penelitian lebih lanjut mengenai kualitas pelayanan Passenger Service, jadwal, rute, beserta penerapan protokol-protokol kesehatan di Kereta Commuter Indonesia yang akan terus mengalami perubahan di masa kenormalan baru ini, demi mencegah penyebaran virus corona melalui kluster transportasi massal.

Terkait saran praktis, diharapkan pihak Manajemen Kereta Commuter Indonesia, agar tetap mempertahankan kualitas penerapan protokol kesehatan berdasarkan aspek Cleanliness, Healthy, Safety and Environmental Sustainability (CHSE) baik melalui sosialisasi maupun himbauan secara langsung kepada wisatawan, agar dapat meningkatkan rasa aman dan nyaman bagi wisatawan domestik dalam menggunakan Kereta Commuter Indonesia. Bagi Passenger Service, diharapkan bisa lebih tanggap lagi kedepannya dan lebih ramah lagi kepada wisatwan domestik. 


\section{Kepustakaan}

Basu, Swasta dan Irawan. 2008. Manajemen Pemasaran Modern. Yogyakarta: Liberty.

Cooper, John Fketcher, David Gilbert and Stephen Wanhill. (1995). Tourism, Principles and Practice. London: Logman.

Dinas Pariwisata Provinsi DKI Jakarta, 2021. "Explore Transportation". Diakses dari www.jakarta-tourism.go.id. Tanggal 10 Febuari 2021.

Ghozali, Imam. 2005. Aplikasi Analisis Multivariate dengan SPSS. Semarang: Badan Penerbit UNDIP.

Lewis, R.C. \& Booms, B.H. (1983). "The marketing aspects of service quality" in Berry, L., Shostack, G. and Upah, G. (eds.). Emerging perspectives on services marketing: American Marketing Association Chicago

Ningsih \& Suryalena. "Pengaruh Kualitas Pelayanan Terhadap Kepuasan Konsumen Pada PT. Kereta Api Indonesia (Persero) Divisi Regional II Sumatra Barat Padang Pariaman". JOM Fisip. Vol. 5 No. 1 (2018):1-5. Neliti.com. (diakses pada 22 Desember 2020).

Sunyoto, Danang. 2012. Dasar-dasar Manajemen Pemasaran. Yogyakarta: Buku Seru.

Tjiptono, F dan G. Chandra. (2011). Service, Quality, dan Satifaction. Yogyakarta: ANDI.

Tjiptono, Fandi. 1995. Strategi Pemasaran. Yogyakarta: Andi. 